\title{
Pola Dakwah Tradisionalis Di Kampung Adat Cireundeu
}

\author{
Ahmad Aliadin \\ UIN Sunan Gunung Djati Bandung \\ ahmadaliadin9@gemail.com \\ Acep Aripudin \\ UIN Sunan Gunung Djati Bandung \\ Iwan Sopwandin \\ UIN Sunan Gunung Djati Bandung \\ Anwar Shadikin \\ UIN Sunan Gunung Djati Bandung
}

\begin{abstract}
The success of a missionary in delivering da'wah cannot be separated from the effective pattern he uses. Tabligh or Da'wah is a moral force that is able to drive social change and offers an alternative in building the future dynamics of the ummah, by taking the right, creative and wise ways and strategies. This paper aims to describe the pattern of da'wah in the Cireundeu Cimahi Traditional Village. This research uses descriptive analysis method with a qualitative approach. Data collection techniques used are observation, interviews, and documentation studies. The results of this study explain that Ustad Abdullah uses a traditionalist pattern, namely conveying Islamic messages or teachings from the yellow book. Using the method of delivery by word of mouth, by action, and equipped with writings from books, magazines or relevant leaflets obtained from outside. Cultural communication used is low context communication. Several factors caused the development of da'wah in the Cirenden village to be hampered, namely: 1) Ingrained customs; 2) lack of creativity of missionaries; 3) limitations of missionaries; 4) The method of da'wah is monotonous; 5) The negative mindset of the followers (adherents of Sunda Wiwitan) towards Muslims; 6) there is no motivation of religious figures.
\end{abstract}

Keywords: Da'wah Pattern, Traditionalist, Cireundeu

\begin{abstract}
Abstrak
Keberhasilan seorang mubaligh dalam menyampaikan dakwah tidak terlepas dari pola efetif yang digunakannya. Tabligh atau Dakwah merupakan kekuatan moral yang mampu menggerakan perubahan sosial serta menawarkan satu alternatif dalam membangun dinamika masa depan umat, dengan menempuh cara dan strategi yang benar, keratif dan bijak. Tulisan ini bertujuan untuk memaparkan pola dakwah di Kampung Adat Cireundeu Cimahi. Penelitian ini menggunakan metode analisis deskriptif dengan pendekatan kualitatif. Teknik pengumpulan data yang digunakan yaitu observasi, wawancara, dan studi dokumentasi.
\end{abstract}


Hasil penelitian ini menjelaskan bahwa Ustad Abdullah menggunakan pola tradisionalis, yaitu menyampaikan pesan-pesan atau ajaran Islam yang berasal dari kitab kuning. Menggunakan metode penyampaian Bil Lisan, Bil Hal, dan dilengkapi dengan tulisan dari buku, majalah atau selembaran relevan yang didapatkan dari luar. Komunikasi budaya yang digunakan yaitu komunikasi konteks rendah. Beberapa faktor yang menyebabkan perkembangan dakwah di kampung cirendeu terhambat, yaitu: 1) Adat Istiadat yang mendarah daging; 2) kurangnya kreatifitas mubaligh; 3) keterbatasan mubaligh; 4) Metode dakwah yang monoton; 5) Mindset negatif para penghayat (penganut sunda wiwitan) terhadap orang Islam; 6) tidak adanya motivasi figure keagamaan.

Kata Kunci: Pola Dakwah, Tradisionalis, Cireundeu

\section{Pendahuluan}

Indonesia merupakan salah satu negara yang kaya akan keberagaman. Mulai dari suku bangsa, bahasa, serta kebudayaan yang masing-masing wilayah memiliki ciri khasnya sendiri dan berbeda dengan wilayah lainnya. Edward Burnett Taylor berpendapat bahwa kebudayaan ialah keseluruhan yang kompleks, yang di dalamnya terkandung pengetahuan, kepercayaan, kesenian, moral, hukum, adat istiadat, dan kemampuan-kemampuan lain yang didapat seseorang sebagai anggota masyarakat. Dari budaya-budaya yang masih sangat abstrak tersebut kemudian menjelma menjadi wujud yang lebih kongkrit seperti yang terdapat pada sikap dan prilaku. ${ }^{1}$

Budaya ini tumbuh dan mekar salah satunya dari adanya keragaman agama dan kepercayaan yang dianut oleh masyarakat Indonesia. Seperti yang dikatakan Geertz (1992: 13), bahwa wahyu membentuk suatu struktur psikologis dalam benak manusia dalam pandangan hidupnya, yang menjadi sarana individu atau kelompok individu yang mengarah pada tingkah laku mereka. ${ }^{2}$

Dalam keragaman etnis budaya akan terdapat kesatuan nilai universal yang bersumber dari akal sehat, fitrah kemanusiaan dan peninggalan budaya leluhur masingmasing etnis. Meskipun umumnya nilai-nilai tersebut berasal dari agama samawi. Samawi yang berarti agama langit. ${ }^{3}$ Disebut agama langit karena dianggap diturunkan dari langit berupa wahyu, tiga agama besar yang termasuk pada agama samawi, yakni: Yahudi, Kristen dan Islam. Ketiga agama tersebut memiliki sejumlah tradisi yang hampir sama namun juga terdapat perbedaan yang mendasar dalam inti ajarannya. Ketiganya telah memberikan pengaruh yang besar dalam kebudayaan manusia di

${ }^{1}$ Heni Gustini, Studi Budaya Di Indonesia, 17 (Bandung: Pusaka utama, 2012).

${ }^{2}$ Acep Aripudin, Dakwah Antar Budaya (Bandung: Remaja Rosdakarya, 2012).

3S Septiani, "Pesan Dakwah Dalam Upacara Tradisi Rebo Wekasan Di Situgunung ( Studi Deskriptif Tentang Pesan Dakwah Terhadap Upacara Tradisi Rebo Wekasan Di Situgunung Desa Gede Pangrango, Kecamatan Kadudampit, Kabupaten Sukabumi )'”' (Bandung, 2021), http://digilib.uinsgd.ac.id/12050/5/4_bab1.pdf. 
berbagai belahan dunia. Dalam terminologi teknis agama, peninggalan ini sering disebut sebagai urf (pengetahuan tentang norma dan nilai yang di sepakati dan diketahui). Urf ini merupakan faktor perekat keragaman budaya sekaligus menjadi salah satu faktor terjadinya konflik. ${ }^{4}$

Warga kampung Cireundeu tetap memegang teguh kepercayaannya turun temurun sampai sekarang walaupun kepercayaan mereka tidak diakui oleh Negara Indonesia. Namun demikian, mereka tetap hidup rukun dengan penganut agama lain, bahkan untuk menjaga keharmonisan hidup antar beragama maka mereka tidak ada larangan untuk menikah pada orang yang tidak satu agama. ${ }^{5}$

Para tokoh kampung adat cireundeu saling memahami akan tradisi yang turun temurun dari nenek moyang meraka. Bagi tokoh agama Islam khususnya para mubalig, budaya yang melekat di kampung adat cireundeu itu menjadi suatu tantangan tersendiri dalam berdakwah. Lalu bagaimana pola dakwah para da'i sehingga perjuangannya tidak mengusik kerukunan antar warga?

Penulis bertujuan untuk menguraikan bagaimana pola dakwah yang diterapkan di Kampung Adat Cirendeu. Pentingnya sebuah pola yang dilakukan oleh mubaligh, maka pesan tersebut akan tersampaikan dengan. Tabligh atau Dakwah merupakan kekuatan moral yang mampu menggerakan perubahan sosial serta menawarkan satu alternatif dalam membangun dinamika masa depan umat, dengan menempuh cara dan strategi yang benar, keratif dan bijak. ${ }^{6}$ Oleh karena itu, sudah seharusnya pola tabligh harus diterapkan oleh para mubaligh dengan titik awal perencanaan yang matang.

Penelitian ini menggunakan metode analisis deskriptif dengan pendekatan kualitatif, yaitu dengan memaparkan segala sesuatu yang erat hubungannya dengan masalah yang diteliti, menginterprestasikan data dan memecahkan masalah yang ada. ${ }^{7}$ Penggunaan pendekatan kualitatif dalam penelitian ini dimaksudkan agar memperoleh gambaran tentang fenomena sosial yang sistematis, faktual mengenai fakta-fakta, sifatsifat dan hubungan fenomena mengenai pola dakwah yang digunakan oleh dai'/mubalig di Kampung Adat Cireundeu kepada mad'unya yaitu masyarakat kampung adat Cireundeu. Sebagaimana menurut Boghan dan Taylor, metodologi kualitatif berupa kata-kata tertulis atau lisan dari orang-orang dan perilaku yang dapat diamati. ${ }^{8}$

Pengumupulan data dilakukan melalui 1) observasi, dilakukan untuk mendapatkan gambaran langsung terhadap kampung adat cireundeu; 2) wawancara, jenis wawancara ini dilakukan dengan model Defth interview yaitu wawancara mendalam terhadap kampung adat Cireundeu, kepada responden atau informan dalam mengumpulkan data berupa pendapat atau mengenai kenyataan di dalamnya, sehingga data memiliki keabsahan dan dapat dipercaya. 3) studi dokumentasi, digunakan untuk

${ }^{4}$ Gustini, Studi Budaya Di Indonesia.

5Ira Indrawardana, "Berketuhanan Dalam Perspektif Kepercayaan Sunda Wiwitan," MELINTAS 30, no. 1 (April 1, 2014): 105, https://doi.org/10.26593/mel.v30i1.1284.105-118.

${ }^{6}$ Asep Muhyiddin, Metode Pengembangan Dakwah, 15 (Bandung: Pusaka utama, 2018).

${ }^{7}$ Bahtiar Wardi, Metodologi Penelitian Ilmu Dakwah (Jakarta: Logos, 2014).

${ }^{8}$ Lexy Moleong, Metodologi Penelitian Kualitatif (Bandung: Remaja Rosdakarya, 2014). 
mengumpulkan data-data dari buku ataupun sumber data lainnya yang mengandung keterangan dan penjelasan serta pemikiran mengenai fenomena yang masih aktual dan berkaitan dengan kampung adat Cireundeu. ${ }^{?}$

\section{Hasil Dan Pembahasan}

Cireundeu merupakan salah satu Kampung Adat yang terletak di Kelurahan Leuwigajah, Kecamatan Cimahi Selatan, Kota Cimahi Jawa Barat. Secara fisik nampak seperti desa yang seluruh masyarakatnya masih mempertahankan tradisi leluhur. Namun, pada kenyataannya Cireundeu hanya berupa satu rukun warga (rukun warga 10) dari keseluruhan 20 rukun warga dyang ada di Kelurahan Leuwi Gajah Kecamatan Cimahi Selatan Kota Cimahi Jawa Barat. ${ }^{10}$

Cireundeu berasal dari nama "pohon reundeu", karena sebelumnya di kampung ini banyak sekali populasi pohon reundeu. Pohon reundeu itu sendiri ialah pohon untuk bahan obat herbal. Maka dari itu kampung ini di sebut Kampung Cireundeu. ${ }^{11}$ Kehidupan masyarakat Cireundeu tidak jauh berbeda dengan rukun warga lainnya yang terdapat di kawasan pinggiran kota. Hanya saja yang membuat Cireundeu menjadi terkenal seperti sekarang yakni beberapa kelompok masyarakatnya memilih rasi (beras singkong) sebagai makanan pokoknya dan menjadikan Sunda wiwitan sebagai suatu kepercayaan di sebagian Masyarakat setempat. ${ }^{12}$ Lebih tepatnya Cireundeu bukan merupakan Kampung Adat ataupun Masyarakat Adat, tetapi lebih tepatnya merupakan kelompok adat karena hanya sebagian masyarakat saja yang masih mempertahankan dan menjalankan tradisi leluhurnya. ${ }^{13}$ Meski demikian, tetap saja wilayah tersebut lebih dikenal dengan Kampung Adat.

Transformasi yang terjadi pada masyarakat adat Cireundeu dan nilai-nilai kearifan lokal masyarakat adat Cireundeu merupakan hal wajar seperti yang tertuang dalam pepatah Sunda yang masyarakat adat Cireundeu sendiri yakini, "orang sunda kudu ngindung ka waktu, mibapa ka jaman" yang berarti bahwa orang Sunda harus menyesuaikan diri dengan perubahan zaman. ${ }^{14}$ Keyakinan Sunda wiwitan di Cireundeu lambat laun mulai terpengaruh oleh ajaran agama Islam dan Kristen meskipun sesepuh

'Sugiyono, Metodologi Penelitian Pendidikan Kuantitatif Kualitatif Dan R\&D (Bandung: Alfabeta, 2014).

${ }^{10}$ HOdKAC, "Hasil Observasi Di Kampung Adat Cireundeu” (Cimahi, 2018).

${ }^{11}$ Cimahikota.go.id, "Mengenal Kampung Adat Cireundeu," 2019, https://cimahikota.go.id/index.php/artikel/detail/1139-mengenal-kampung-adat-cireundeu.

${ }^{12}$ Fauzan Ahdi Widyaputra, Evi Novianti, and Iriana Bakti, "Citra Kampung Adat Cireundeu Pada Ritual Suraan," PRofesi Humas Jurnal Ilmiah Ilmu Hubungan Masyarakat 3, no. 2 (February 12, 2019): 219, https://doi.org/10.24198/prh.v3i2.14953.

13Pirie Marie Tramontane, "Tinjauan Konsistensi Masyarakat Kampung Adat Cireundeu Dalam Melestarikan Adat Istiadat Leluhur," ULTIMART Jurnal Komunikasi Visual 10, no. 2 (March 23, 2018): 12-23, https://doi.org/10.31937/ultimart.v10i2.769.

${ }^{14}$ Vega Saktipraditha and Anne Maryani, "Implementasi Makna Prinsip 'Ngindung Ka Waktu, Mibapa KaJaman' Terhadap Produk Kebudayaan Kampung Adat Cireundeu," Prosiding Manajemen Komunikasi 5, no. 2 (2019): 815-21. 
adat, tokoh pemuda dan warga masyarakat adat Cireundeu lainnya mengelak bahwa kepercayaan Sunda wiwitan merupakan agama asli mereka (Orang Sunda). Tidak sedikit pula banyak orang yang menyamakan kepercayaan Sunda wiwitan di Cireundeu dengan agama samawi (Islam dan Kristen). Ada juga sebagian masyarakat ada yang memusyrikan para penganut keyakinan Sunda wiwitan di Cireundeu hanya karena masih menjalankan tradisi leluhur. ${ }^{15}$

\section{Kehidupan Masyarakat Muslim Kampung Adat Cireundeu}

Kehidupan masyarakat muslim di kampung adat Cirendeu tidak beda jauh dengan kehidupan masyarakat muslim pada umumnya. Kehidupan masyarakat muslim di Cireundeu lebih mendominasi dari agama kepercayaan lainnya. Hal tersebut dapat dilihat dari peta sebagai berikut. ${ }^{16}$

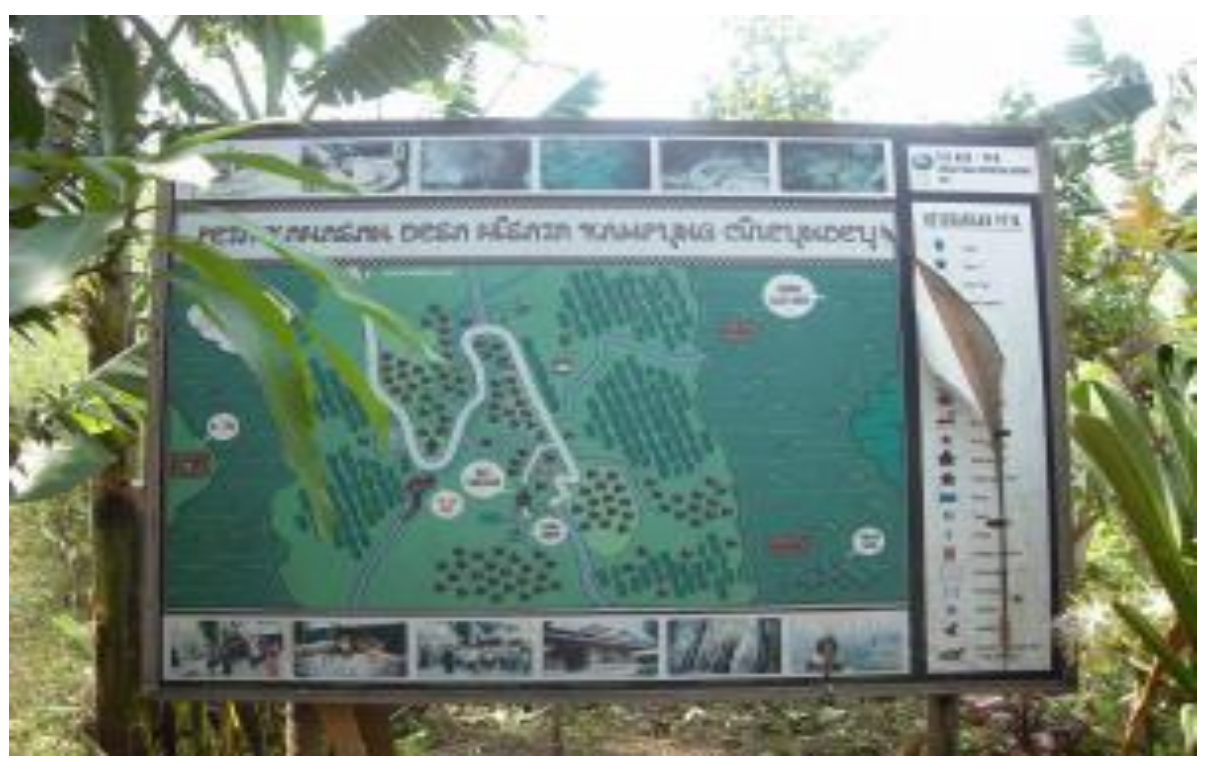

Gambar 1. Peta persebaran penganut kepercayaan di Cirendeu.

Peta tersebut menjelaskan bahwa:

1. Kampung Cireundeu RW 10 RT 1 adalah semuanya Muslim.

2. Kampung Cireundeu RW 10 RT 2 adalah mayoritas penganut Sunda Wiwitan.

3. Kampung Cireundeu RW 10 RT 3 adalah Imbang antar Muslim dan Penghayat.

4. Kampung Cireundeu RW 10 RT 4 adalah semuanya Muslim.

5. Kampung Cireundeu RW 10 RT 5 adalah mayoritas Muslim.

Muslim menjadi mayoritas di kampung Cireunde. Penganut sunda wiwitan kurang lebih hanya 30 persen dari jumlah keseluruhan yang ada di cireundeu. Hal

${ }^{15} \mathrm{HWdKDA}$, Hasil wawancara dengan Ketua DKM Al-Ikhlas Pak Abdullah, 2018.

${ }^{16}$ HSDmPPKKAD, "Hasil Studi Dokumentasi Mengenai Persebaran Penganut Kepercayaan Di Kampung Adat Cirendeu” (Cimahi, 2018). 
tersebut melatarbelakangi sebagian besar masyarakat tidak mau di sebut kampung adat cireundeu, cukup di sebut warga adat atau komunitas adat saja. Meski mayoritas masyarakatnya muslim, dari segi pemahaman tentang islam masih dasar, bahkan ada sebagian muslim di Cireunde yang belum bisa membaca Alquran. Hal ini diakibatkan karena kurangnya jumlah tokoh agama.

\section{Perkembangan Dakwah di Kampung Adat Cireundeu}

Kegiatan dakwah di kampung adat Cireundeu mulai berkembang pada tahun 1997, berkat seorang guru agama bernama Pak Dadang Sukarna yang berasal dari kota Subang, beliau di bantu oleh Ustad Abdullah. Tahun 2000 Pak Dadang menjabat sebagai ketua RW 10. Pada saat itu, dakwah mereka berjalan lancar. Hal tersebut karena mereka memiliki peran penting di struktural masyarakat cireundeu, sehingga setidaknya tidak sulit untuk sosialisasi kepada msyarakat. ${ }^{17}$

Kurangnya sosok atau pigure muslim yang dapat dijadikan panutan menjadikan Dadang sebagai tokoh yang berperan penting dalam berkembangnya Islam di Cirendeu. Pak Dadang Sukarna sempat membentuk satu Yayasan yang di namakan Yayasan percikan iman. Yayasan tersebut dipimpin langsung oleh beliau, ini menjadikan yayasan pertama yang ada di Cireundeu. Setelah kepergian Dadang karena perpindahan tugas, yayasan Percikan Iman pun tidak ada. Seiring kepergian Pak Dadang, proses dakwah di lanjutkan oleh Ustad Abdullah yang hingga sekarang menjabat sebagai Ketua DKM Masjid Jami di Cireunde.

Pada awalnya masjid berbentuk Mushola yang dibangun pada tahun 1986 oleh H. Mulya yang berasal dari luar kampung. Beliau berasal dari Leuwigajah. Tahun 1990 H. Mulya dibantu oleh Ustad Abdullah menginisiasi perbaikan mushola, dan perbaikan terus berlanjut sampai sekarang hingga berubah menjadi Masjid. Hingga saat ini, di Cirendeu terdapat dua tokoh, yaitu Ustad Abdullah masyarakat memanggilnya Pak Uloh sebagai ketua DKM Al-Ikhlas berlokasi di RT 05 dan Ustad Maman sebagai ketua DKM Nurul Huda berlokasi di RT 04. Dahulu sebelum adanya Pak Dadang dan Ustad Abdullah, di kampung ini kondisi Ustad jauh lebih tertinggal dibanding kondisi sesepuh adat, baik dari segi pergaulan, ekonomi dan lain sebagainya sehingga proses dakwah terhambat. Hal ini menunjukan bahwa faktor integritas Mubaligh mempengaruhi aktifitas dan ke efektifitasan dakwah. ${ }^{18}$

Ada beberapa faktor yang menyebabkan perkembangan dakwah di Cireundeu sulit berkembang, diantaranya:

1. Adat Istiadat yang sudah mendarah daging.

Problem dakwah yang paling mendasar di kampung adat Cireundeu ini adalah adat

Istiadat yang sudah mendarah daging, mereka selalu menolak ajaran Islam karena

${ }^{17} \mathrm{HWdKDA}$, Hasil wawancara dengan Ketua DKM Al-Ikhlas Pak Abdullah.

${ }^{18}$ HOdKAC, "Hasil Observasi Di Kampung Adat Cireundeu." 
bagi mereka Islam itu agama yang berkebudayaan Arab, bahkan sholat dan ritual lainnyapun mengikuti kebudayaan Arab. ${ }^{19}$

2. Mubaligh yang kurang kreatif

Mubaligh yang kurang kreatif menjadi salah satu ploblematika dakwah di kampung ini, karena sampai saat ini dikampung adat Cireundeu belum pernah ada mubaligh yang benar-benar kompeten di bidangnya. Ketua DKM pun bukan benar-benar orang yang kompeten, hanya saja sering mengamalkan ajaran Islam, sehingga beliau minim metode dan inovasi. Pada akhirnya kegiatannya pun dianggap monoton, dan ketertarikan mad'u dalam hal ini masyarakat pun sedikit menurun.

3. Keterbatasan tenaga pendakwah/ mubaligh

Faktor penghambat perkembangan dakwah di kampung adat Cireundeu adalah sedikitnya mubaligh yang ada di kampung adat Cireundeu. Sempat terjadi kasus ada seorang anak yang semangat untu mengaji tetapi karena pengajarnya sakit dan tidak ada yang bisa menggantikan, akhirnya anak itu pun tidak jadi mengaji, hal ini tidak jarang terjadi karena mubaligh yang masih terbatas.

4. Metode Dakwah

5. Mindset negatif para penghayat (penganut sunda wiwitan) terhadap orang Islam Mindset negatif penganut Sunda Wiwitan terhadap ajaran Islam menjadi salah satu penghambat perkembangan dakwah, karena mindset negatif para penghayat ini membuat dakwah Islam susah untuk masuk kepada para penghayat, jangankan diterima oleh hati para penghayat, diterima sebagai ilmupun akan sulit.

Dari penuturan ketua adat beliau mengutarakan bahwa tidak suka, tetapi ajaran islam membodohi umatnya. Beliau menuturkan pengalamannya yang sempat mengaji ajaran Islam di sekolah, menurut guru agamanya bahwa Allah itu tidak boleh disamakan dengan mahluknya, tetapi di Televisi beliau menonton seorang mubaligh kondang mengakatan segala kekuasaan ada ditangan Allah. Kejadian tersebut membuat beliau berpikir kenapa Allah disamakan dengan mahluk, bukannya Allah itu berbeda dengan mahkluk. Dari sanalah beliau beranggapan bahwa Islam itu hanya bisa membodohi umatnya. ${ }^{20}$

6. Kurang adanya motivasi figure keagamaan

Menurut beberapa orang muslim di kampung adat Cireundeu motivasi figure keagaman disini kurang, karena dilihat kondisinya sampai saat ini belum ada yang diberi kesempatan jiarah ke tanah suci. Menurutnya meskipun yang ziarah ke tanah suci bukan orang yang pandai agama tetapi setidaknya jika di kampung ini sudah ada haji maka akan terlihat ada kekentalan ajaran Islamnya.

\section{Pola Dakwah di Kampung Adat Cireundeu}

Meskipun pada perjalanannya masih terdapat banyak kekurangan, tetapi proses dakwah disini tak pernah berhenti. Bahkan sedemikian rupa Ketua DKM mengupayakan metode dan pola-pola dakwah yang efektif.Pola Dakwah yang diterapkan di Kampung Adat Cirendeu adalah Pola Tradisionalis. Dakwah tradisionalis

2018.

${ }^{19} \mathrm{HWdKAKCAE}$, Hasil wawancara dengan Ketua Adat Sunda Wiwitan Abah Eman,

${ }^{20} \mathrm{HWdKAKCAE}$. 
adalah dakwah yang bertema sesuatu yang irrational, berpandangan tidak ilmiah, atau lawan dari segala bentuk kemodernan. Tradisionalisme dianggap sebagai aliran yang berpegang teguh pada keaslian Agama, melalui penafsiran terhadap kitab suci secara rigid dan literalis. ${ }^{21}$ Dari segi etimologis, tradisional berarti kecenderungan untuk melakukan sesuatu yang telah dilakukan oleh pendahulu, dan memandang masa lampau sebagai otoritas dari segala bentuk yang telah mapan. Secara sederhana tradisionalisme adalah paham yang berdasar pada tradisi dan merupakan lawan dari modernisme, liberalisme, radikalisme, dan fundamentalisme. ${ }^{22}$

Beberapa metode dakwah yang digunakan antara lain sebagai berikut: ${ }^{23}$

1. Bil Lisan

Seperti Ceramah, dan Pengajian-pengajian.

2. Bil Hal

Menggunakan percontohan dalam suatu kegiatan kebajikan atau melakukan sesuatu kebajikan yang dapat mendorong seseorang atau sekelompok orang lain untuk merubah dirinya dari suatu keadaan kepada yang lebih baik, dan lebih sesuai dengan ajaran Islam. Contohnya shalat tepat waktu.

3. Tulisan

Media yang digunakan berupa buku, majalah dan selebaran yang didapatkan beliau dari luar.

Melihat dari metode atau pola yang digunakan dan cara berfikirnya mengenai Islam, dapat dikatakan pemahaman Ustad Abdullah bersifat atau beraliran tradisonalis. Hal ini bisa di lihat dari penyampaian materi yang bersumber dari kitab-kitab klasik atau kitab kuning.

Pola komunikasi yang digunakan adalah komunikasi konteks rendah yang berarti menyampaikan langsung makna dan tujuannya. ${ }^{24}$ Digunakan Ustad Abdullah dan tokoh agama lainnya dalam beberapa kegiatan pengajian dan Keagamaan besar seperti: ${ }^{25}$

1. Pengajian Ibu-ibu Mingguan

Pengajian mingguan ibu-ibu di Cireunde ini di adakan setiap hari kamis sehabis

Sholat ashar. Diadakan di Masjid Al-Ikhlas, berlangsung selama dua jam.

${ }^{21}$ Abdul Hamid, "Dakwah Dalam Perspektif Paradigma Tradisionalisme Dan Reformisme," Kordinat: Jurnal Komunikasi Antar Perguruan Tinggi Agama Islam 15, no. 1 (April 1, 2016): 89-104, https://doi.org/10.15408/kordinat.v15i1.6310.

${ }^{22}$ Hasri Hasri, "Studi Kritis Pemikiran Pemikir Islam Kontemporer," Kelola: Journal of Islamic Education Management 1, no. 1 (October 24, 2016): 33-47, https://doi.org/10.24256/kelola.v1i1.427.

${ }^{23} \mathrm{HWdKDA}$, Hasil wawancara dengan Ketua DKM Al-Ikhlas Pak Abdullah.

${ }^{24}$ Aripudin, Dakwah Antar Budaya.

${ }^{25}$ HSDmPPKKAD, "Hasil Studi Dokumentasi Mengenai Persebaran Penganut Kepercayaan Di Kampung Adat Cirendeu." 


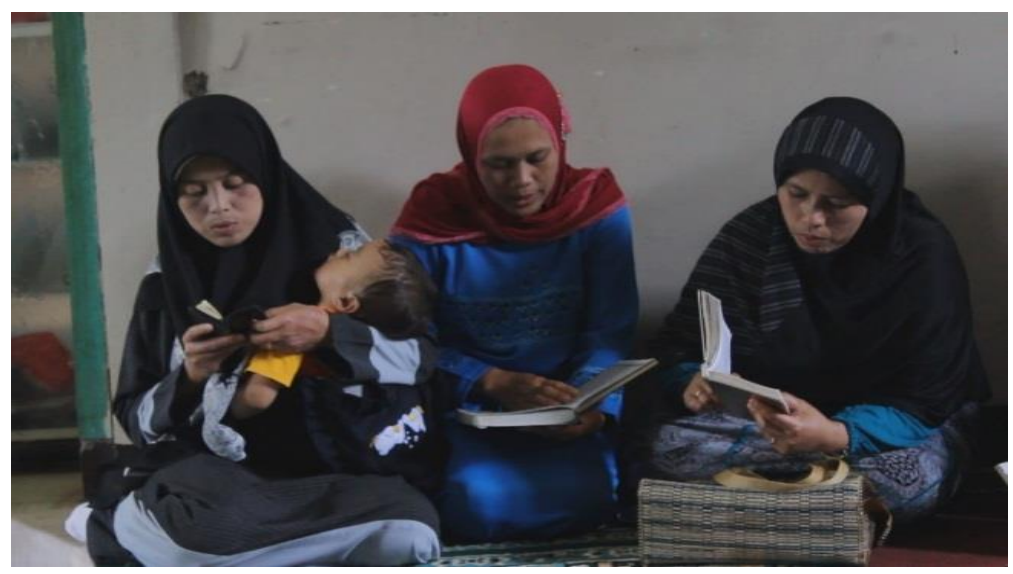

Gambar 2. Pengajian Rutin Ibu-Ibu

2. Pengajian anak-anak

Pengajian anak-anak diadakan setiap hari bertempat di teras Masjid Al-Ikhlas dengan dua Guru perempuan yakni teh Ifah dan teh Iwi, di mulai bada ashar sampai jam 17.00 atau sampai menjelang magrib.

Materi pokok yang di kaji yaitu Iqro dan Alquran karna itu anak terbagi menjadi dua ada sebagian anak yang mengaji Iqro dan sebagian anak lainnya mengaji Al-Quran setelah mengaji Iqro dan Al-Quran biasanya di lanjut dengan menulis Iqro dan Al-Quran yang telah dikaji, bercerita tentang sejarah Nabi-Nabi, atau praktekperakter ibadah seperti Sholat, Wudhu dan lain-lain.

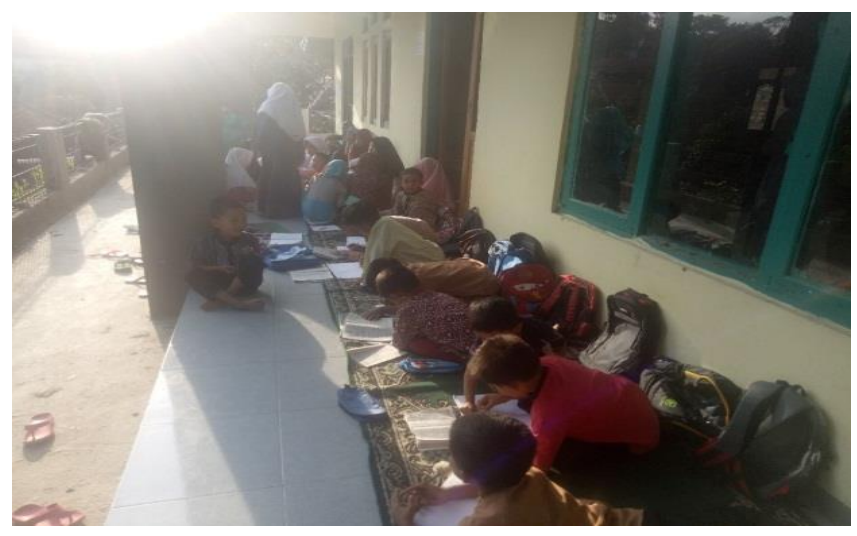

Gambar 3. Proses Pengajian Anak-Anak

3. Pengajian malam jumat

Pengajian malam Jumat dilaksanakan setelah shalat Isya sampai selesai, pengajian di hadiri oleh laki-laki dari kalangan orangtua dan anak muda. 


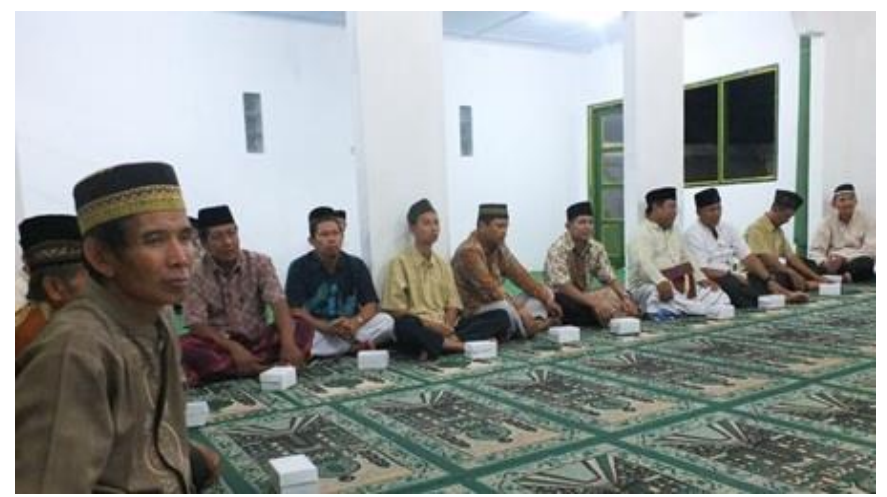

Gambar 4. Pengajian Malam Jum'at

Pengajian diisi dengan pembacaan surat Yasin yang di barengi dengan tawasul kepada Rasul, Tabiin, Guru-guru, Orang tua, dan orang yang telah meninggal, tak jarang ada sebagian warga yang membawa air mineral saat pengajian sebagai air doa atau air keberkahan.

4. Kegiatan Tahunan

Pengajian ini diadakan setiap setahun sekali, dan biasanya pengisi materi berasal dari luar kampung adat Cireundeu, kegiatan tersebut meliputi:

a. Muharoman

b. Rajaban atau peringatan Isra Miraj

Muludan atau peringatan kelahiran Nabi Muhamad Saw.

\section{Penutup}

Pola dakwah yang digunakan Ustad Abdullah meskipun tradisionali, tetapi memberikan dampak yang sangat signifikan terhadap perkembangan Islam di Kampung Adat Cireundeu. Masyarakat yang masih terbilang sederhana memudahkan komunikasi mubalig, sehingga komunikasi yang digunakan pun dengan konteks rendah. Dengan penyampaian yang langsung, tegas, serta lugas memudahkan masyarakat untuk mencernanya.

Jumlah masyarakat muslim yang mendominasi sebenarnya memberikan keuntungan kepada para Mubalig, karena tidak perlu sembunyi-bunyi dan takut oleh pemeluk kepercayaan lain. Hal tersebut hanya sebatas peluangnya saja, karena belum adanya mubalig yang kompeten disana. Meski demikian, minat masyarakat untuk mendalami dan mengamalkan ajaran Islam sangat antusias. Terbukti dengan selalu banyaknya yang menghadiri pengajian baik mingguan maupun tahunan. 


\section{Daftar Pustaka}

Aripudin, Acep. Dakwah Antar Budaya. Bandung: Remaja Rosdakarya, 2012.

Cimahikota.go.id. "Mengenal Kampung Adat Cireundeu," 2019. https://cimahikota.go.id/index.php/artikel/detail/1139-mengenal-kampungadat-cireundeu.

Gustini, Heni. Studi Budaya Di Indonesia. 17. Bandung: Pusaka utama, 2012.

Hamid, Abdul. "Dakwah Dalam Perspektif Paradigma Tradisionalisme Dan Reformisme." Kordinat: Jurnal Komunikasi Antar Perguruan Tinggi Agama Islam 15, no. 1 (April 1, 2016): 89-104. https://doi.org/10.15408/kordinat.v15i1.6310.

Hasri, Hasri. "Studi Kritis Pemikiran Pemikir Islam Kontemporer." Kelola: Journal of Islamic Education Management 1, no. 1 (October 24, 2016): 33-47. https://doi.org/10.24256/kelola.v1i1.427.

HOdKAC. “Hasil Observasi Di Kampung Adat Cireundeu.” Cimahi, 2018.

HSDmPPKKAD. "Hasil Studi Dokumentasi Mengenai Persebaran Penganut Kepercayaan Di Kampung Adat Cirendeu.” Cimahi, 2018.

Indrawardana, Ira. "Berketuhanan Dalam Perspektif Kepercayaan Sunda Wiwitan." MELINTAS 30, no. 1 (April 1, 2014): 105. https://doi.org/10.26593/mel.v30i1.1284.105-118.

Moleong, Lexy. Metodologi Penelitian Kualitatif. Bandung: Remaja Rosdakarya, 2014.

Muhyiddin, Asep. Metode Pengembangan Dakwah. 15. Bandung: Pusaka utama, 2018.

Saktipraditha, Vega, and Anne Maryani. "Implementasi Makna Prinsip Ngindung Ka Waktu, Mibapa KaJaman' Terhadap Produk Kebudayaan Kampung Adat Cireundeu.” Prosiding Manajemen Komunikasi 5, no. 2 (2019): 815-21.

Septiani, S. "Pesan Dakwah Dalam Upacara Tradisi Rebo Wekasan Di Situgunung ( Studi Deskriptif Tentang Pesan Dakwah Terhadap Upacara Tradisi Rebo Wekasan Di Situgunung Desa Gede Pangrango, Kecamatan Kadudampit, Kabupaten Sukabumi )".” 2021. http://digilib.uinsgd.ac.id/12050/5/4_bab1.pdf.

Sugiyono. Metodologi Penelitian Pendidikan Kuantitatif Kualitatif Dan R\&D. Bandung: Alfabeta, 2014. 
$236 \mid \mathrm{Jurnal}$ Dakwah dan Komunikasi, Vol.6 No.2, 2021

Tramontane, Pirie Marie. “Tinjauan Konsistensi Masyarakat Kampung Adat Cireundeu Dalam Melestarikan Adat Istiadat Leluhur." ULTIMART Jurnal Komunikasi Visual 10, no. 2 (March 23, 2018): 12-23. https://doi.org/10.31937/ultimart.v10i2.769.

Wardi, Bahtiar. Metodologi Penelitian Ilmu Dakwah. Jakarta: Logos, 2014.

Widyaputra, Fauzan Ahdi, Evi Novianti, and Iriana Bakti. "Citra Kampung Adat Cireundeu Pada Ritual Suraan." PRofesi Humas Jurnal Ilmiah Ilmu Hubungan Masyarakat 3, no. 2 (February 12, 2019): 219. https://doi.org/10.24198/prh.v3i2.14953. 